\title{
PENGARUH LOGOTHERAPY DAN AKTIVITAS SPIRITUAL TERHADAP MAKNA HIDUP LANSIA
}

\author{
Indar Widowati*, Sri Hidayati, Afiyah Sri Harnany \\ Poltekkes Kemenkes Semarang Prodi Keperawatan Pekalongan \\ Jl. Perintis Kemerdekaan Pekalongan Telp. (0285) 421642 \\ Korespondensi: indarwidowati@gmail.com
}

\begin{abstract}
Elderly is a group that is prone to psychosocial disorders and loses the meaning of life due to aging (degenerative). Boredom is a symptom of the emergence of a vacuum of existence or function of existence (Frankl, 2006). Existential frustration is a condition when a person feels lost in his life. Frankl stated that the lack of fulfillment of meaning in life would lead to meaningless life, emptyness, aridity, lack of purpose in life, feeling bored, meaningless, and apathetic (in Bastaman 2007: 80). Logotherapy is one of psychotherapy which is a method that helps individuals in the search for meaningfulness of life. Spiritual activity is one form of activity that includes the values underlying the life of a whole person. The purpose of this study was to analyze the effect of logotherapy and spiritual activities on increasing the meaning of life in the elderly. This type of research is a quasi experimental pretest-posttest control group. The mean increase in the life meanings of the elderly before treatment was 3.53 and after the treatment became 16.53 with $\rho$ value: $0.00<0.05$ ). The mean treatment group that received logotherapy intervention and spiritual activity was greater (13.00) compared to the control group $(11.20)$ which only received logotherapy treatment with $\rho$ value: $0.00<0.05)$. There was a significant effect on changes in life meanings in the treatment group that received logotherapy ( 00 value $0.00<0.05$ ), there was a significant effect on changes in life meanings in the control group who received logotherapy and spiritual activities (00 value $0.00<0,05)$, Logotherapy and spiritual activities in the treatment group were more effective in influencing the life meaning of the elderly than in the control group who only received logotherapy alone ( $\rho$ value: 0.00 ).
\end{abstract}

Kata kunci: Logotherapy, Spiritual activity, Meaning of life of the elderly

\begin{abstract}
ABSTRAK
Lansia merupakan kelompok yang rentan terhadap gangguan psikososial dan kehilangan makna hidup akibat proses menua (degeratif). Perasaan bosan merupakan gejala munculnya kevakuman eksistensi atau fungsi eksistensi (Frankl, 2006). Frustasi eksistensial merupakan sebuah kondisi ketika seseorang merasa kehilangan makna dalam hidupnya. Frankl menyatakan bahwa belum terpenuhinya makna dalam hidup akan menimbulkan penghayatan hidup tanpa makna (meaningless), hampa, gersang, tidak memiliki tujuan hidup, merasa bosan, tidak berarti, dan apatis (dalam Bastaman 2007:80). Logoterapi merupakan salah satu psikoterapi yaitu sebuah metode yang membantu individu dalam pencarian kebermaknaan hidup. Aktivitas spiritual merupakan salah satu bentuk aktivitas yang mencakup nilainilai yang melandasi kehidupan manusia seutuhnya. Tujuan penelitian ini yaitu untuk menganalisis pengaruh logoterapi dan aktivitas spiritual terhadap peningkatan makna hidup pada lansia. Jenis penelitian ini adalah quasi eksperimental Pretest-postest Control Group Disign. Rerata peningkatan makna hidup lansia sebelum perlakuan sebesar 3,53 dan setelah perlakuan menjadi 16,53 dengan $\rho$ value: $0,00<0,05)$. Rerata kelompok perlakuan yang mendapat intervensi logoterapi dan aktivitas spiritual lebih besar $(13,00)$ dibanding dengan kelompok kontrol $(11,20)$ yang hanya mendapat perlakuan logoterapi dengan $\rho$ value: $0,00<0,05)$. Ada pengaruh signifikan terhadap perubahan makna hidup pada kelompok perlakuan yang mendapatkan logoterapi ( $\rho$ value $0,00<0,05)$, ada pengaruh signifikan terhadap perubahan makna hidup pada kelompok kontrol yang mendapatkan logoterapi dan aktivitass spiritual ( $\rho$ value $0,00<0,05$ ), Logoterapi dan aktivitas spiritual pada kelompok perlakuan lebih efektif pengaruhnya terhadap peningkatan makna hidup lansia dibanding pada kelompok kontrol yang hanya mendapatkan logoterapi saja ( $\rho$ value $: 0,00$ ).
\end{abstract}

Kata Kunci: Logoterapi, Aktivitas spiritual, Makna hidup lansia 


\section{PENDAhULUAN}

Hampir tidak disangsikan lagi bahwa salah satu keberhasilan pembangunan bidang kesehatan, adalah meningkatnya umur harapan hidup. Umur harapan hidup di Indonesia mencapai 72 tahun, dengan penduduk lansia mencapai angka 7\% pada tahun 2012 (BPS, 2013 dalam Runingga, 2015). Di Kota Pekalongan penduduk lansia mencapai angka 7,7\% pada tahun 2015, dengan umur harapan hidup 74,09 tahun (BPS, Kota Pekalongan, 2016).

Seiring dengan meningkatnya jumlah lansia di Indonesia, meningkat pula permasalahan kesehatan akibat proses penuaan atau degenertif. Proses menua selalu akan diiringi dengan penurunan kondisi fisik, psikologis, sosial, spiritual, dan seksual (Ebersole, 2010; Halock, 2004, yang saling berinteraksi satu sama lainnya. Perubahan tersebut berbeda untuk setiap orang, namun yang pasti bagi individu yang berusia panjang akan mengalami proses penuaan.

Penurunan secara fisik, mental, sosial, minat, dan adanya sikap yang tidak menyenangkan dari masyarakat memaksa lansia mengurangi aktivitas rutinya. Hal tersebut mengakibatkan lansia terisolir, tidak berkembang, dan kesempatan untuk mengaktualisasikan dirinya semakin kecil. Tekanan sosial yang diterima lansia akan mengembangkan munculnya perasaan tidak berguna, bosan, dan rendah diri (Hurlock, 2004). Perasaan-perasaan tersebut, bila tidak segera diatasi akan membahayakan kelangsungan hidup lansia. Perasaan bosan merupakan gejala munculnya kevakuman eksistensi atau fungsi eksistensi (Frankl, 2006). Frustasi eksistensial merupakan sebuah kondisi ketika seseorang merasa kehilangan makna dalam hidupnya.

Hidup tanpa makna mengakibatkan hidup terasa kosong, tanpa harapan, dan hampa. Frankl menyatakan bahwa belum terpenuhinya makna dalam hidup akan menimbulkan penghayatan hidup tanpa makna (meaningless), hampa, gersang, tidak memiliki tujuan hidup, merasa bosan, tidak berarti, dan apatis (dalam Bastaman 2007:80).

Logotherapy memandang manusia sebagai totalitas dari dimensi spiritual (kerohanian), disamping dimensi ragawi (fisik) dan kejiwaan (psikis). Menurut Frankl, landasan logotherapy meliputi: 1) dalam setiap keadaan, termasuk dalam penderitaan sekalipun, kehidupan ini selalu mempunyai makna, 2) kehendak untuk hidup bermakna merupakan motivasi semua manusia, 3) dalam batas-batas tertentu, manusia memiliki kebebasan dan tanggung jawab pribadi untuk memilih dan menentukan makna dan tujuan hidupnya, 4) hidup bermakna dapat diperoleh dengan merealisasikan nilai-nilai kreatif, nilai-nilai penghayatan serta nilai-nilai dalam bersikap (Batasman, 2007).

Selain itu, untuk memasuki dimensi spiritual diperlukan suatu bentuk kegiatan atau aktivitas yang dapat meningkatkan makna hidup. Salah satu bentuk kegiatan tersebut adalah bimbingan rohani Islam. Hasil penelitian Napsiah (2015) membuktikan bahwa bimbingan rohani Islam meningkatkan makna hidup dan konsep diri pasien diabetes melitus.

\section{PERMASALAHAN}

Logotherapy merupakan salah satu psikoterapi untuk memaknai hidup seseorang, dimana klien sendiri yang harus memutuskan apakah tugas hidupnya, bertanggung jawab terhadap masyarakat atau hati nuraninya dengan bantuan terapis.

Aktivitas spiritual berupa bimbingan rohani Islam yang merupakan salah satu bentuk aktivitas spiritual yang mencakup nilai-nilai yang melandasi kehidupan manusia seutuhnya, terbukti dapat meningkatkan makna hidup. 
Oleh sebab itu, rumusan masalah yang diajukan berupa pertanyaan penelitian, yaitu: 1) apakah ada pengaruh logotherapy terhadap makna hidup lansia, 2) apakah ada pengaruh aktivitas spiritual terhadap makna hidup lansia, 3) apakah ada perbedaan pengaruh makna hidup antara kelompok intervensi yang diberikan logotherapy dan aktivitas spiritual dengan kelompok kontrol yang hanya mendapat perlakuan logotherapy.

\section{HIPOTESIS}

3.1 Ada pengaruh logotherapy terhadap makna hidup pada lansia

3.2 Ada pengaruh logotherapy dan aktivitas siritual terhadap makna hidup lansia

3.3 Ada perbedaan pengaruh makna hidup lansia antara kelompok intervensi yang diberikan logotherapy dan aktivitas spiritual dengan kelompok kontrol yang hanya diberikan logotherapy

\section{TINJAUAN PUSTAKA}

\subsection{Lansia}

Proses menua atau aging bukan merupakan suatu penyakit, tetapi suatu proses alami pada manusia. Batasan lansia masih berbeda pendapat diantara beberapa ahli di bidang gerontik atau lansia. Hurlock (2004) menyatakan bahwa lansia merupakan tahap perkembangan akhir dari seorang individu, yang dibagi dalam usia lanjut dini (berkisar antara usia 60-70tahun), dan lansia mulai pada usia 70 tahun hingga akhir kehidupan seseorang. Batasan lansia menurut World Health Organization (WHO, 2010), seseorang yang telah berusia 60 tahun atau lebih. Sedangkan menurut Undangundang No. 13 tahun 1998, seseorang yang berusia 60 tahun atau lebih masuk dalam kategori lansia.

Seseorang yang telah memasuki masa lansia menurut Hurlock (2004) memiliki beberapa karakteristik, yaitu: 1) usia lansia merupakan periode kemunduran, bahwa seseorang yang memasuki masa lansia akan mengalami kemunduran fisik maupun mental secara perlahan-lahan dan bertahap, 2) lansia mempunyai status minoritas, yaitu status dalam beberapa hal untuk mengecualikan lansia untuk tidak berinterksi dengan kelompok lain, 3) penyesuaian yang buruk, sikap lansia yang tidak menyenangkan menyebabkan lansia mengembangkan konsep diri yang negatif, 4) keinginan yag sangat kuat untuk menjadi muda kembali, beberapa lansia dengan status minoritasnya, secara alami telah membangkitkan keinginan untuk tetap muda selama mungkin. Lebih lanjut Hurlock (2004), menyatakan bahwa lansia lebih identik dengan masa penurunan kondisi fisik, mental, maupun minat.

Perubahan-perubahan pada lansia, meliputi: perubahan fisik, perubahan motorik, perubahan kemampuan mental, dan perubahan minat (Hurlock, 2004). Penurunan kondisi fisik terjadi pada usia lansia dan sebagian besar perubahan terjadi ke arah yang memburuk, proses dan kecepatannya sangat berbeda untuk masingmasing individu. Perubahan fisik meliputi perubahan penampilan, bagian dalam tubuh, fungsi fisiologis, panca indera, dan seksual. Perubahan motorik, lansia cenderung lambat dalam koordinasi gerak dan aktivitas.

Kemampuan mental lansia semakin berkurang karena adanya penurunan fungsi dan kemampuan dalam panca indera. Perubahan mental yang dialami lansia adalah menurunnya kemampuan mengingat, mempelajari hal-hal baru, menurunnya kecepatan dalam mencapai kesimpulan, berkurangnya kapasitas berpikir kreatif, cenderung lemah dalam mengingat hal-hal yang baru, kecenderungan untuk 
mengenang sesuatu yang terjadi pada masa lalu meningkat, kehilangan rasa dan keinginan terhadap hal-hal yang lucu dan menurunnya perbendaharaan kata yang digunakan (Hurlock 2004).

Perubahan minat terjadi karena hubungan antara jumlah keinginan dan minat pada seluruh tingkat usia ternyata erat dengan keberhasilan penyesuaian. Lansia mengalami keputusasaan maka masa lalu hanya akan dinilai negatif dan tampak dari perilaku keragu-raguan dan kemurungan. Putus asa berarti tanpa harapan. Tugas perkembangan yang lain adalah terkait dengan ritualisme yaitu integral versus sapentisme. Integral maksudnya adalah bijaksana dan telah mampu memaknai kehidupan sedangkan lansia yang belum bisa menunjukkan sikap bijaksana dan senang memberi petuah-petuah yang bersifat dogmatis dikatakan berinteraksi dengan ritualism sapentism.

\subsection{Logotheraphy}

Logotherapy merupakan aliran psikologi yang memberi kajian tentang fenomena makna hidup (the meaning of life), dan pengembangan hidup bermakna yang dikemukakan oleh Viktor E. Logotherapy merupakan sebuah metode yang membantu individu dalam pencarian kebermaknaan hidup. Logotherapy dalam perannya memasuki dimensi spiritual dari eksistensi manusia sebagai potensi yang harus diisi dengan mengoptimalkan kesadarannya secara penuh akan sesuatu. Untuk itu Logotherapy, memperhatikan manusia sebagai sebuah keberadaan yang perhatian utamanya adalah untuk mengisi dan aktualisasi nilai-nilai kehidupan (Frank1, 2006).

Menurut Frankl (dalam Bastaman 2007) terdapat tiga komponen kebermaknaan hidup, dimana satu dan lainnya mempunyai hubungan yang erat dan saling mempengaruhi. Ketiga komponen itu adalah: 1) Kebebasan berkehendak (freedom of will), 2) Kehendak hidup bermakna (will to meaning), 3) Makna hidup (meaning of life).

Kebebasan berkehendak (freedom of will) adalah kebebasan yang dimiliki oleh seseorang untuk menentukan sikap baik terhadap kondisi lingkungan maupun kondisi diri sendiri dalam hidupnya dan menentukan apa yang dianggap penting dan baik bagi dirinya. Kebebasan berkehendak bukan merupakan kebebasan dari bawaan biologis, kondisi psikososial dan kesejarahannya. Kebebasan dalam hal ini bukan kebebasan yang mutlak dan tanpa batas, karena manusia diciptakan selain dengan kelebihan, juga dilengkapi dengan keterbatasan masing-masing. Keterbatasan manusia berupa keterbatasan secara fisik atau ragawi (tenaga, daya tahan, stamina, usia), aspek kejiwaan (kemampuan, keterampilan, kemauan, ketekunan, bakat, sifat, tanggung jawab pribadi), aspek sosial budaya (dukungan lingkungan, kesempatan, tanggung jawab sosial, ketaatan pada norma), dan aspek kerohanian (iman, ketaatan beribadah, cinta kasih). Istilah yang sesuai adalah "the self determining being", artinya manusia dalam batas-batas tertentu memiliki kemampuan dan kebebasan untuk mengubah kondisi hidupnya guna meraih kondisi hidup yang berkualitas. Kebebasan harus disertai rasa tanggung jawab agar tidak berkembang menjadi kesewenang-wenangan.

Kehendak hidup bermakna (will to meaning), setiap orang menginginkan dirinya menjadi orang yang bermartabat dan berguna bagi dirinya sendiri, keluarga, lingkungan kerja, masyarakat sekitar dan berharga di mata Tuhan. Setiap orang pasti punya cita-cita dan tujuan hidup yang jelas dan penting yang akan diperjuangkan 
dengan penuh semangat, sebuah tujuan hidup yang menjadi arahan segala kegiatannya. Setiap manusia mendambakan dirinya sebagai orang yang bertanggungjawab terhadap dirinya sendiri serta menjadi orang yang mampu menentukan sendiri apa yang akan dilakukannya dan apa yang paling baik bagi dirinya dan lingkungannya. Setiap manusia pun ingin dicintai dan mencintai orang lain karena dengan demikian diri akan merasa berharga, berarti, dan merasa bahagia. Sebaliknya tidak ada manusia yang menginginkan kehidupan tanpa tujuan, karena hal demikian akan menjadikan kehidupan yang tidak jelas, tanpa arah dan tidak mengetahui apa yang diinginkan dan dilakukannya. Keadaan hati yang gersang, hampa, merasa tidak berguna timbul karena kehidupan yang dijalani diwarnai oleh perasaan jemu dan apatis.

Makna hidup (Meaning in Life/MIL) adalah sesuatu yang dianggap penting, benar dan didambakan serta memberi nilai khusus bagi seseorang. Kehidupan akan memuaskan dan individu akan mampu mengatasi berbagai kesulitan dan masalah dalam hidupnya apabila kehidupannya memiliki makna (Frankl 2006). Makna yang diberikan adalah makna pribadi, tidak ada seorang pun yang diuntungkan oleh pencapaian tujuan mereka dan keingintahuan mereka berhenti pada diri mereka sendiri. Makna hidup akan selalu berubah tetapi tidak pernah hilang.

Terdapat tiga cara yang dapat ditempuh untuk menemukan makna hidup yaitu 1) melalui pekerjaan atau perbuatan, 2) dengan mengalami sesuatu atau melalui seseorang, 3) melalui sikap terhadap penderitaan. Makna hidup bisa ditemukan saat berhadapan dengan penderitaan (Frankl 2006).

Dengan mengembangkan konsep yang dimiliki Frankl, Crumbaugh dan Maholick menjelaskan bahwa karakteristik individu dengan pencapaian makna hidup dapat dilihat dari ciri-cirinya yakni: a) memiliki tujuan yang jelas, yaitu segala sesuatu yang dilakukan memiliki kejelasan akan tujuan hidup, b) kepuasan hidup, sejauhmana seseorang dapat menikmati dan merasa puas menjalani aktivitas, c) kebebasan berkehendak, yakni mampu mengendalikan kebebasan hidup yang dilakukan secara bertanggungjawab, d) kontrol diri, dalam keadaan apapun manusia masih bisa melestarikan kebebasan spiritual dan kebebasan berfikir, e) sikap terhadap kematian, yaitu bagaimana seseorang berpandangan dan kesiapannya menghadapi kematian, f) mampu memiliki alasan untuk tetap eksis (Frankl, 2006).

Bastaman (2007) mengungkapkan bahwa penghayatan hidup yang tidak bermakna jika berlarut-larut tidak teratasi akan menjelma menjadi neurosis noogenik, karakter totaliter, dan karakter konformis. Neurosis noogenik merupakan suatu gangguan perasaan yang cukup menghambat prestasi dan penyesuaian diri seseorang, dan biasanya tampil dalam keluhan-keluhan serba bosan, hampa dan penuh keputusasaan, hilangnya minat dan inisiatif, serta merasa bahwa hidup tidak ada artinya sama sekali.

Karakter totaliter adalah gambaran pribadi dengan kecederungan untuk memaksakan tujuan, kepentingan, dan kehendak sendiri dan tidak bersedia menerima masukan dari orang lain. Sangat peka kritik dan biasanya akan menunjukkan reaksi menyerang kembali secara emosional. Karakter konformis adalah gambaran pribadi dengan kecenderungan kuat untuk selalu berusaha mengikuti dan menyesuaikan diri kepada tuntutan lingkungan sekitarnya serta bersedia untuk mengabaikan keinginan dan kepentingan diri sendiri. 
Frankl (dalam Anggriany 2006) menyimpulkan bahwa frustrasi adalah suatu fenomena yang semakin banyak ditemui dalam masyarakat modern. Menurut Frankl (2006), frustrasi eksistensial sejauh tidak disertai dengan gejala-gejala klinis tertentu bukan suatu penyakit dalam pengertian klinis, melainkan lebih merupakan suatu penderitaan batin yang berkaitan dengan ketidakmampuan individu untuk menyesuaikan diri dan mengatasi masalah-masalah pribadi dengan baik.

Pemunculan frustrasi eksistensial berkaitan dengan fenomena umum yang dialami oleh manusia saat ini, yaitu manusia tidak lagi memiliki kepastian mengenai apa yang seharusnya dilakukan. Frankl (dalam Anggriany 2006), mengemukakan bahwa frustrasi eksistensial dapat diketahui melalui beberapa manifestasinya, antara lain: neurosis kolektif, neurosis pengangguran, neurosis hari minggu, dan neurosis eksekutif.

Terdapat beberapa metode dalam logotherapy salah satunya dalam bentuk logophylosophy (Kirehbach, 2002 dalam Batasman, 2007), dan kesadaran terhadap nilai (Hutzel \& Jerkins, 1990 dalam Batasman, 2007), yang semuanya berdasarkan atas personal exsistensial analysis (Batasman, 2007), yaitu: 1) teknik intensi paradoksial, teknik ini berdasarkan konsep kebebasan berkeinginan (freedom of will), dan kemampuan mengambil sikap (to take a stand) terhadap kondisi diri sendiri dan lingkungan. 2) Direfleksi (Dereflection), teknik ini dengan memanfaatkan kemampun trasendensi diri (self-transcendence), yang ada pada setiap manusia dewasa, artinya kemampuan membebaskan diri dan tidak memperhatikan lagi kondisi yang tidak nyaman, kemudian mencurahkan kepada hal-hal yang positif dan bermanfaat. 3) Logophylosopy, merupakan teknik Logotherapy dengan mengajarkan kepada individu untuk lebih menerima atau adaptif terhadap respon nyeri, perasaan bersalah dan kematian. 4) Bimbingan Rohani, merupakan bimbingn khusus terhadap klien dengan penyakit yang tidak dapat disembuhkan. 5) Kesadaran terhadap nilai (Value Awarness Technique/VAT), merupakan teknik yang membantu individu menyadari nilai-nilai atau potensi yang masih dimiliki untuk digunakan meskipun dalam kondisi sulit.

\subsection{Instrumen Pengukuran Makna Hidup}

Pengukuran makna hidup lansia dikenal dengan nama "meaning life questionare" yang diadopsi dari the meaning in life (Steger, Frazier et al, 2006 dalam Nauli 2011). Instrumen ini terdiri atas dua pengkajian, yaitu pengkajian tentang makna hidup saat ini yang telah dicapai (presence), dan pengkajian terhadap proses pencarian makna hidup (search). Terdiri atas 10 pertanyaan dengan menggunakan skala likert, yang dikategorikan atas 5 pertanyaan tentang kondisi makna hidup yang telah dicapai, dan 5 pertanyaan tentang pencarian makna hidup.

\subsection{Aktivitas Spiritual}

Aktivitas spiritual adalah kegiatan yang dilakukan untuk memenuhi kebutuhan spiritual guna mendekatkan diri kepada Yang Maha Kuasa demi mencari arti dan tujuan hidup, kebutuhan untuk mencintai dan dicintai serta rasa keterikatan dan kebutuhan untuk memberikan dan mendapatkan maaf (Gunarso, 2009).

Ruang lingkup aktivitas spiritual yaitu semua jenis kegiatan aktivitas spiritual yang dilakukan secara rutin oleh para lansia baik secara langsung maupun tidak langsung. Berdo'a, kunjungan ke tempat ibadah, puasa, pengajian merupakan contoh kegiatan aktivitas spiritual (Gunarso, 2009). Aktivitas spiritual sering dihubungkan 
dengan hidup aktif dan keterikatan sosial untuk mengisi waktu senggang. Aktivitas spiritual dapat memberikan arti hidup, rasa berarti, harapan hidup sehingga dapat meningkatkan makna hidup lansia di akhir kehidupannya.

Beberapa teori menjelaskan hubungan antara aktivitas spiritual dengan proses penuaan. Kegiatan spiritual berkaitan dengan rasa berarti dan harapan yang mampu membantu individu secara efektif mengatasi stres, ansietas dan depresi yang berhubungaan dengan proses penuaan. Secara psikologis aktivitas spiritual meningkatkan rasa optimis dan kebahagiaan pada lansia. Salah satu bentuk aktivitas spiritual berupa bimbingan rohani Islam merupakan proses pemberian bantuan secara indivual maupun dalam keompok-kelompok kecil agar dapat keluar dari berbagai kesulitan agar memperoleh ridha Allah di dunia dan akhirat.

Materi yang disampaikan dalam bimbingan rohani Islam berupa: Akidah, Ibadah dan Muamalah. Akidah merupakan pokok kepercayaan agama Islam. Akidah Islam disebut tauhid dan merupakan inti dari kepercayaan. Akidah merupakan I'tiqad bathiniyyah yang mencakup masalah-masalah yang erat hubungannya dengan rukun iman (Amin, 2009 dalam Nafsiah, 2015). Keimanan kepada akidah merupakan langkah pertama dalam menimbulkan perubahan besar dalam kepribadian, sebab akidah tauhid dalam diri manusia melahirkan tenaga spiritual besar yang mengubah pengertiannya tentang dirinya, orang lain, kehidupan dan seluruh alam semesta. Akidah memberikan pengertian baru tentang kehidupan dan memenuhi kalbunya dengan cinta kepada Allah, Rasulullah, orang disekitarnya dan umat manusia pada umumnya, serta mampu menciptakan perasaan damai dan tenteram.

Ibadah menurut (Mahmud, 1994 dalam Nafsiah, 2015), meliputi masalah ta'abud kepada Allah dengan segala yang telah diwajibkan kepada kaum muslimin, seperti dua kalimat syahadat, shalat, puasa, zakat, haji bagi yang telah mampu, dzikir dan segala hal yang disyariatkan Allah. Ibadah yang disyariatkan agama Islam dapat mempengaruhi kesehatan, apabila dilakukan sesuai dengan pedoman yang disampaikan langsung oleh Allah melalui Nabi Muhammad, serta mengindahkan perintah dan larangan Allah.

Selain akidah dan ibadah, materi bimbingan juga berupa muamalah. Muamalah mencakup segala bentuk sifat yang diupayakan (shifah kasbiyah) oleh seorang Muslim, seperti akhlak individual, sikap kepada Allah, diri, sesama dan makhluk lainnya (Mahmud, 1994 dalam Nafsiah, 2015). Dalam Islam dijelaskan pentingnya akhlak yang baik, seperti sikap seorang mukmin jika diuji dengan datangnya penyakit, Islam mengajarkan untuk senantiasa optimis dalam menghadapi penyakit yang diderita.

\section{METODE}

Penelitian ini merupakan penelitian kuantitatif dengan Pretest- postest Control Group Design (Pocock, 2008), dengan intervensi logotherapy untuk mengetahui peningkatan makna hidup lansia. Sebanyak 30 responden direkrut dengan teknik Simple Random Sampling, meliputi 15 responden pada kelompok perlakuan, dan 15 responden pada kelompok kontrol. Pengukuran dalam penelitian dilakukan 2 kali, yaitu sebelum perlakuan (pre) dan setelah perlakuan (post) . Terapi ini dilakukan sebanyak 5 kali, yaitu 4 kali sesi logoterapi dan 1 sesi bimbingan rohani.

Data penelitian akan dianalisis dengan bantuan program komputer SPSS versi 16 dengan proses sebagai berikut: Editing, Coding, Entry, Cleaning: Saving, Analysis data. Analisis data meliputi: 1) Univariat digunakan untuk menganalisis secara deskriptif setiap variabel penelitian 
dengan membuat tabel frekuensi dan menguji normalitas data. 2) Analisis bivariat untuk data tingkat makna hidup lansia pada kelompok perlakuan dan kontrol sebelum dan sesudah dilakukan intervensi menggunakan uji paired sample t-test. Analisa perbedaan tingkat makna hidup setelah mendapat intervensi pada kelompok perlakuan dan kontrol menggunakan uji Independent t test

\section{HASIL PENELITIAN}

\subsection{Analisis Makna Hidup Sebelum Perlakuan}

Tabel 1. Makna Hidup Responden Sebelum Perlakuan

\begin{tabular}{lccccc}
\hline \multicolumn{1}{c}{ Variabel } & Kelompok & $\mathrm{N}$ & Mean & SD & Min-Max \\
\hline Makna Hidup & Kontrol & 15 & 3,27 & 0,884 & $2-5$ \\
\cline { 2 - 6 } (pre-test) & Perlakuan & 15 & 3,53 & 0,990 & $2-5$ \\
\hline
\end{tabular}

Tabel 1 tampak bahwa rata-rata skor makna hidup pada kelompok kontrol sebesar 3,27 dengan rentang nilai 2-5. Pada kelompok perlakuan rata-rata skor makna hidup sebesar 3,53 dengan rentang nilai 1-5. Artinya responden pada kelompok kontrol dan intervensi memiliki makna hidup pada rentang yang sama, meskipun ratarata skor pada kelompok kontrol sedikit lebih rendah.

\subsection{Analisis Makna Hidup Setelah Perlakuan}

Tabel 1 Makna Hidup Responden Setelah Perlakuan

\begin{tabular}{cccccccc}
\hline Variabel & Kelompok & $\mathbf{N}$ & Mean & SD & SE & t & p value \\
\hline Makna Hidup & Kontrol & 15 & 12,07 & 1,163 & 0,300 & 23,129 & 0,000 \\
\cline { 2 - 8 } & Perlakuan & 15 & 3,27 & 1,163 & 0,300 & 8,919 & 0,000 \\
\hline
\end{tabular}

Tabel 2 tampak bahwa rata-rata skor makna hidup pada kelompok perlakuan lebih rendah sebesar 8,80 dibanding kelompok kontrol. Artinya peningkatan makna hidup lebih baik pada kelompok intervensi dibandingkan kelompok kontrol.

Hasil uji statistik didapat $\rho$ value $0,00<0,005$, artinya terdapat perbedaan penurunan depresi pada kelompok intervensi dan kelompok kontrol.

\subsection{Analisis Perubahan Makna Hidup Sebelum dan Setelah Perlakuan}

Tabel 3. Analisis Perubahan Makna Hidup Sebelum dan Setelah Perlakuan

\begin{tabular}{llrrrrrr}
\hline Variabel & Kelompok & N & Mean & SD & SE & t & $\begin{array}{c}\boldsymbol{\rho} \\
\text { value }\end{array}$ \\
\hline Makna & Kontrol & & & & & & \\
hidup & Sebelum & 15 & 3,27 & 0,884 & 0,228 & 23,129 & 0,00 \\
& Setelah & 15 & 12,07 & 1,163 & 0,300 & & \\
& Selisih & & 11,20 & & & & \\
\cline { 2 - 7 } & Perlakuan & & & & & & \\
& Sebelum & 15 & 3,53 & 0,990 & 0,256 & 29,787 & 0,00 \\
& Setelah & 15 & 16,53 & 1,125 & 0,291 & & \\
& Selisih & & 13,00 & & & & \\
\hline
\end{tabular}

Tabel 3 tampak bahwa terjadi perubahan makna hidup pada kelompok perlakuan sebelum dan sesudah mendapat intervensi. Nilai makna hidup meningkat sebesar 13,00. Hal ini berarti peningkatan makna hidup ke arah lebih baik. Nilai ratarata ini secara statistik bermakna, yaitu $\rho$ value $0,00<0,05$. 
Tabel 3 tampak bahwa terjadi perubahan makna hidup pada kelompok kontrol sebelum dan sesudah mendapat perlakuan. Nilai makna hidup meningkat sebesar 11,200. Hal ini berarti peningkatan makna hidup ke arah lebih baik. Nilai rata-rata ini secara statistik bermakna, yaitu $\rho$ value $0,02<0,05$

\section{PEMBAHASAN}

\subsection{Pengaruh Logoterapi Terhadap Makna Hidup}

Hasil penelitian membuktikan bahwa logoterapi yang diberikan pada kelompok kontrol meningkatkan makna hidup lansia secara bermakna. Peningkatan makna hidup pada lansia tersebut karena kegiatan logoterapi dilakukan secara berkelompok. Terapis memberikan kesempatan untuk melakukan hubungan interpersonal sesama anggota kelompok. Kegiatan tersebut untuk saling membagi pengalaman, dan umpan balik positif sesama anggota kelompok dan memotivasi semua lansia untuk aktif.

Selain itu, kegiatan secara kelompok ini, juga menyebabkan lansia merasa dirinya dihargai, sehingga merasa lebih berkualitas dan bermakna dalam hidupnya. Seseorang merasa bermakna bagi orang lain ketika kehadirannya diterima dan berpengaruh terhadap orang lain, lansia merasa sebagai bagian integral dari lingkunganya.

Peningkatan makna hidup lansia juga disebabkan oleh pelaksanaan logoterapi yang dilakukan. Lansia diajarkan dan dilatih langsung oleh terapis dan peneliti, serta dilakukan pendampingan selama kegiatan berlansung. Notoadmojo (2010), menyatakan bahwa adanya perubahan tindakan berperilaku dapat terjadi karena adanya dorongan/pemberian informasi dan diskusi. Kegiatan ini mengarahkan lansia untuk mengikuti proses belajar dan dilakukan dengan praktik langsung sehingga menjadi lebih efektif.

Selain itu, kegiatan ini juga disertai buku kerja yang memuat jadwal kegiatan sehari-hari yang terarah dan terstruktur untuk menemukan makna hidup. Hal tersebut membuat lansia lebih termotivasi untuk mengikuti kegiatan yang berlangsung dalam menemukan makna hidup. Lansia dibimbing cara menemukan makna hidup melalui kegiatan seharihari, dengan prinsip seseorang akan bermakna jika mampu mengaktualisasikan potensi yang dimiliki. Juka seseorang tidak mampu mengaktualisasikan potensi yang dimiliki akan mengakibatkan kehampaan eksistensial dan perasaan tidak bermakna. Kehampaan eksistensial sering ditemukan pada lansia dengan tanda adanya kecemasan, merasa kesepian, perasaan hampa, kebosanan, merasa tidak berguna dan depresi.

Frankl (1984), dalam Nauli (2011), menyatakan bahwa kondisi kehampaan eksistensial bukan karena individu merasa tertekan karena kondisi kelemahan, ketidakberdayaan serta perasaan tidak berharga, tetapi disebabkan oleh persepsi individu terhadap kehidupan yang membuat tidak bermakna.

Hal ini berarti logoterapi dapat meningkatkan makna hidup lansia. Prinsip logoterapi bahwa hidup manusia memiliki makna yang penting yang harus dicapai dalam hidup, setiap individu memiliki kebebasan dalam menemukan makna hidupnya, serta makna hidup dapat ditemukan dalam kehidupan individu sendiri dalam kondisi apapun, dan disertai dengan keyakinan (Batasman, 2007; Hutzell, 1990, Schunberg, 2003 \& Rogina, 2008 dalam Nauli, 2011). 
Kemampuan makna hidup lansia merupakan akhir dari kemampuan lansia dalam menyadari dan melihat kondisi diri, dengan menyadari dan menggali potensi yang masih dimiliki untuk melakukan sesuatu yang bermakna melalui kegiatan seharihari. Lansia untuk menyadari secara penuh tanggung jawab, pilihan dirinya untuk menemukan makna hidup di akhir kehidupannya.

\subsection{Pengaruh Logoterapi Dan Aktivitas Spiritual Terhadap Makna Hidup}

Hasil penelitan membuktikan bahwa kelompok perlakuan yang mendapatkan intervensi logoterapi dan aktivitas spiritual (bimbingan spiritual) mengalami peningkatan makna hidup. Rerata sebelum perlakuan sebesar 3,53 dan setelah perlakuan menjadi 16,53 dengan $\rho$ value:0,00

Peningkatan makna hidup lansia disebabkan oleh pelaksanaan logoterapi yang dilakukan. Lansia diajarkan dan dilatih langsung oleh terapis dan peneliti, serta dilakukan pendampingan selama kegiatan berlansung. Notoadmojo (2010), menyatakan bahwa adanya perubahan tindakan berperilaku dapat terjadi karena adanya dorongan/pemberian informasi dan diskusi. Kegiatan ini mengarahkan lansia untuk mengikuti proses belajar dan dilakukan dengan praktik langsung sehingga menjadi lebih efektif.

Pengaruh logoterapi diikiuti oleh pengaruh bimbingan rohani, hal ini menjadikan makna hidup lansia lebih baik atau meningkat

\subsection{Efektivitas Logoterapi Dengan Logoterapi Dan Aktivitas Spiritual Terhadap Makna Hidup Lansia}

Hasil penelitian membuktikan bahwa rerata kelompok perlakuan yang mendapat intervensi logoterapi dan aktivitas sepiritual lebih besar $(13,00)$ dibanding dengan kelompok kontrol $(11,20)$ yang hanya mendapat perlakuan logoterapi dengan $\rho$ value : 0,00 , artinya logoterapi dan aktivitas spiritual lebih efektif menurunkan meningkatkan makna hidup dibanding kelompok yang mendapat intervensi logoterapi saja.

Peningkatan makna hiudup tersebut terjadi karena pengaruh logoterapi ditambah dengan pengaruh aktivitas spiritual. Logoterapi merupakan salah satu metode untuk menemukan makna hidup seseorang

Logoterapi membimbing lansia untuk menemukan makna hidup. Logoterapi dengan teknik VAT (Value Awarness Tehnique), dengan 4 sesi, yaitu: 1) perubahan dan masalah yang dialami lansia, 2) stimuli imajinasi kreatif, 3) memproyeksikan makna dalam kehidupan sehar-hari, 4) evaluasi. Berdasarkan empat sesi tersebut lansia dibimbing oleh terapis dan peneliti untuk menemukan makna hidupnya, mengetahui potensi yang dimiliki sekecil apapun untuk diproyeksikan ke dalam kehidupan seharihari. Selain itu, pelaksanaan logoterapi dilakukan secara kelompok, hal memberikan kesempatan kepada lansia untuk berinteraksi dan berkomunikasi dengan sesama lansia. Hal tersebut dapat meningkatkan harga diri dan penerimaan diri dilingkunganya, sehingga dapat meningkatkan makna hidup.

Pada kelompok perlakuan juga diberikan aktivitas spiritual berupa bimbingan rohani. Materi bimbingan rohani Islam bersumber pada Alquran dan Hadist, yang meliputi aspek keimanan, aspek ibadah, dan aspek muamalah. Runingga (2015), 
bahwa bimbingan rohani secara bermakna meningkatkan makna mhidup lansia.

Berdasarkan hal tersbut, maka peneliti memberikan asumsi bahwa logoterapi dan aktivitas spiritual, apabila diberikan secara bersamaan lebih efektif dalam meningkatkan makna hidup lansia. Kedua terapi tersebut saling melengkapi dan mendukung lansia untuk lebih termotivasi menemukan makna hidup agar bermanfaat bagi diri sendiri, orang lain maupun lingkunganya.

\section{KESIMPULAN}

Ada pengaruh signifikan terhadap perubahan makna hidup pada kelompok perlakuan yang mendapatkan logotherapy ( $\rho$ value $0,00<0,05$ ).

Ada pengaruh signifikan terhadap perubahan makna hidup pada kelompok kontrol yang mendapatkan logotherapy dan aktivitass siritual ( $\rho$ value $0,00<0,05$ ).

Logoterapi dan aktivitas spiritual pada kelompok perlakuan lebih efektif pengaruhnya terhadap peningkatan makna hidup lansia dibanding pada kelompok kontrol yang hanya mendapatkan logoterapi saja ( $\rho$ value : 0,00 )

\section{DAFTAR PUSTAKA}

Anggriany, N. 2006. Motif Sosial dan Kebermaknaan Hidup Remaja Pagaralam

Badan Pusat Statistik. 2016. Pekalongan dalam angka

Batasman, H.D,. 2007. Logoterapi :Psikologi untuk Menemukan Makna Hidup dan Meraih Hidup Bermakna. Jakarta: PT. Raja Grafindo Persada

Daradjat, Zakiyah (2001). Islam dan Kesehatan Mental. Jakarta. Gunung Agung.

Ebersole, KT, Sosnoff, JJ \& Voudrie, SJ,. 2010. The Effect of Knee Joint angle on torque control, Journal of Motor Behaviour, vol 42, pp. 5-10

Frankl, V.E,. 2006. Logoterapi: Terapi Psikologi Melalui Permaknaan Eksistensi. Yogyakarta: Kreasi Wacana.

Hurlock, E.B,. 2004. Psikologi Perkembangan suatu pendekatan sepanjang rentang kehidupan (edisi kelima.). Penerbit Erlangga. Jakarta

Maefina dan Agus (2009). Mengenal Spiritual Lanjut Usia. Yogyakarta. Graha Ilmu.

Napsiah (2015). Hubungan Konsep Diri Dengan Kbermaknaan Hidup Pasien Diabetes Melitus Anggota Prolanis Dr. H. Suwwindi Gubug Kabupaten Grobogan (Analisis Materi Bimbingan Rohani Isslam Pada Penderita Penyakit Kronis. Fakultas Dakwa Dan Komunisai UIN Walisongo Semarang

Nauli, F.A. (2011). Pengaruh Logoterapi Lansia dan psikoedukasi Keluarga Terhadap Depresi dan Kemampuan memaknai Hidup Pada Lansia Di Kelurahan Katulampa Bogor Timur. Tesis. FIK UI. Jakarta.

Notoatmodjo,Sukidjo. (2010). Promosi Kesehatan dan Ilmu Perilaku. cetakan pertama. Rineka Cipta. Jakarta.

Runingga (2015). Hubungan Tingkat Religius dan Tingkat Depresi Lansia Beragaa Islam Di Panti Tresna Wredha Budi Mulia 4 Margaguna, Jakarta Selatan. Skripsi, PSIK Fakultas Ilmu Kedokteran dan Kesehatan UIN Syarif Hidayatullah Jakarta.

Singgih D. Gunarsa (2009). Dari Anak Sampai Usia Lanjut. Jakarta. Gunung Mulia.

WHO (2010), Depression: http://www.who.int mental_health/diperoleh tanggal 3 September 2016 